Lancashire. The Cretaceous sea lay over Anglesey, and Cainozoic folding has carried its base (p. 895) to some 700 or $800 \mathrm{ft}$. above the present sea-level. No great warping is needed to prolong this base over Snowdon, and the excavation of the deep valleys of the highland is ascribed, like the levelling of the "Menaian platform" (p. 783 ), to Pliocene denudation. The contrast between
Snowdonia and the lowland of Anglesey is not due to differential erosion, but to the curve of the Cainozoic anticline, rising to the east.

The details of the glaciation of the island are now for the first time adequately dealt with, and with this last hint of the additions made by Mr. Greenly to British geology, our notice must, ever gratefully, conclude.

\title{
Food Requirements and the Minimum Wage.
}

\begin{abstract}
A WELL-KNOWN and trusted Labour leader A remarked, not very long age, to the writer of the present article, apropos the scientific assessment of food requirements, that "Science leaves me cold." Labour, in common with other parties in the community, has to learn that, unpalatable or no, scientific truth must be faced squarely. Unless the conduct of affairs be laid securely on a sound, scientific basis, and not on sentimentalism, the social edifice will collapse. It is constantly forgotten that the scientific dictum of to-day usually becomes the hackneyed commonplace of to-morrow.
\end{abstract}

Much as the recent proposal to base wages on a sliding scale, rising and falling with the cost of living, is resented, it is an absolutely sound doctrine, and probably the only practicable base to work from without inflicting undue hardship upon the community at large. Many workers seem to resent the utilisation of this base on the ground that it would reduce them, in their opinion, to the level of animals. This is a perfectly unsound deduction, and not only is it unsound; it is unwarranted. The introduction of such a scientific assessment of wages does not reduce the status of the worker.

We all have a right to live, and life is maintained by an adequate ingestion of food. The only practicable basis for the fixation of the level of the minimum wage would seem to be the cost of living. It has been contested by many people who are unacquainted with the methods of science that as all humanity is neither of the same sex nor of equal age and size, and as the work performed by various classes of the community varies within wide limits, as regards both severity and duration, it is impossible to lay down standards which will be uniformly applicable. So far as the minimum wage is concerned, there is abso. lutely no difficulty.

It may be well to state briefly, in the first place, the methods by which science has reached its definite conclusions, as the whole question is dependent on the fact that food is consumed as a source of energy for internal and external work. The demands for internal work are fairly definitely known, and are a function of the mass of the active tissue (mainly muscle) of the body. This fraction will be considered under the terms of basal or standard metabolism-i.e. the energy requirements when the body is in a state of complete repose. In order to assess the amount of work No. 266 I, VOL. I06] done, both internal and external, and the amount of food which must be consumed in order to cover this, it is obvious that there must be some com mon unit to which everything is reduced. The unit most generally utilised is the large calorie, as all forms of energy may finally be reduced to terms of heat. The large calorie is the amount of heat required to raise I kilo. of water from $15^{\circ}$ to I $6^{\circ} \mathrm{C}$.

The number of Calories contained in a unit mass of food can be determined directly by burning the food in a special small steel chamber (the bomb calorimeter) where the heat liberated by the combustion of the food material is taken up by water contained in a water-jacket, the rise of the tem. perature of the water being measured by a sensitive thermometer. The amount of energy given off by the body can also be determined, either directly by measuring the amount of heat given off as heat and estimating the external work done in work units, which, in turn, can also be stated in terms of heat, or indirectly by means of the exact analysis of the expired air, where each litre of oxygen consumed can be calculated in terms of Calories.

The cost of the internal work, the basal metabolism, is, as already mentioned, a function of the amount of active metabolic tissue present in the organism. It is obvious that the actual amount of such tissue cannot be directly determined in the living subject. Formerly it was assumed that the weight of the individual gave a good approximation, and that therefore the Calorie output per kilogram body weight-i.e. including active tissue like muscle and inactive tissue like fat-would be the measure of the cost of internal work. Recent research has shown that such a value is an approximation only; that much more uniform values can be obtained if the weight-factor is correlated with the age and the height of the individual The basal metabolism by the use of suitable formulæ can now be stated in terms of Calories per square metre surface of the body. The mean of a large number of determinations has shown that the basal metabolism of a man between the ages of twenty and fifty on an ordinary diet is 39.7 Calories per square metre surface per hour. It is generally accepted that the "average " man has a surface of about 1.77 square metres, and, therefore, a daily basal metabolism of approximately I 700 Calories-i.e. as cost of internal work.

This method of assessing the basal metabolism 
enables us to deal with the fact that workers vary markedly in physical condition. An objection to the use of a general average for all workers in all trades is that it is frequently found in practice that a certain type of man tends to drift into one type of occupation and a different type into another. It is a case, in the majority of instances, of the survival of the fittest; if a worker is not suited to the trade he has selected he eventually seeks another. But, in spite of this possible segregation-and nothing could be more simple than to make definite allowances if these were required -it is found that the general law of averages can be applied with success.

In order to determine the total daily output of energy by any individual, to the cost of the in. ternal work must be added the increment due to the external work done. In spite of the widely expressed belief that it is quite impossible to correlate the daily work done by different types of workers, let us say that of a postman, a dock labourer, a bricklayer, and a trawler deck-hand, nothing is more easy, provided the appropriate tests are carried out. It is true that the amount of energy spent in the form of external work varies very markedly with the type of work performed and the conditions under which it is çarried out. It may range from the low cost of sedentary work in a warm office or workshop, to the other extreme of hard manual labour under unfavourable conditions in the open air. One of the attempts at the classification of external work is given in the report on food requirements by the Food (War) Committee of the Royal Society. The figures given are net daily (eight-hour) figures to be added to the cost of the basal metabolism.

\begin{tabular}{|c|c|c|c|c|c|}
\hline Sedentary & & & I.ess tha & n 400 & Calories \\
\hline Light work & $\ldots$ & ... & 400 to & 700 & ", \\
\hline Moderate & .. & & 700, & 1000 & \\
\hline Heavy ... & & $\ldots$ & 1100 & 2000 & , \\
\hline
\end{tabular}

In certain types of work the 2000-Calorie limit may be exceeded.

Then, finally, there is the question oi sex. Experimental work has definitely shown that the basal metabolism of women is about 7 per cent. below that of men, and, further, that, except in the lightest forms of manual work, the amount of external work performed is below that of men. It is generally held that the total energy output of women for the twenty-four hours is 17 per cent. below that of men. 'This divergence between the male and female metabolism can ultimately be referred back to two simple factors: (I) the relative weights, and (2) the relative proportion of muscle in the two sexes. As regards the first, it is common knowledge that the average woman weighs less than the average man; and, as regards the second, it is equally well known that the average woman is not so muscular as the average man-the average muscle in the case of man forms about 45 per cent. of the total weight, whereas in the woman it forms only about 38 per cent. It therefore follows that the expendiNO. 266I, VOL. IO6] ture of energy will be greater in the case of the male, making the assumption, of course, that each worker, male and female, is working at his or her optimum rate.

It is to be regretted that in this class of investigation, although a certain amount of work has becn done, Britain has not played a prominent part. Compared with the work carried out both on the Continent and in the United States, the experimental work here has been almost negligible. The special apparatus and the facilities for such research have been lacking. The Intcr-Allied Scientific Food Commission, which sat during the later stages of the war, did recommend that a special institute for such research should be founded in each country, but, so far, nothing has been done here.

As regards the practical aspect of the question, the investigations of Miss Lindsay and Miss Ferguson in Glasgow have thrown considerable light on the problem. Before the war, for example, it was found that the average family in receipt of $r l$. per week could obtain, expending, it is true, about 73 per cent. of the total income on food, 3 I63 Calories per "man" 1 per day, roughly at the rate of 453 Calories per penny. Early in 1917 an income of $r l$. ros. did not suffice. At present, in a recent Government return (Labour Gazette, September, I920), it is shown that the cost of food alone is 167 per cent. above pre-war level, and if the overall expenditure be taken there is an increase of $16 \mathrm{r}$ per cent. The following table, from data kindly supplied by Miss Ferguson, gives a good idea of the change in the cost of living during the past six years:-

\begin{tabular}{|c|c|c|c|c|c|c|c|c|c|c|}
\hline \multicolumn{2}{|c|}{ Commodity } & $\begin{array}{l}\text { June, } \\
\text { rg14 }\end{array}$ & $\begin{array}{c}\text { June, } \\
\text { 1915 }\end{array}$ & $\begin{array}{r}\text { Nov., } \\
1915\end{array}$ & $\begin{array}{l}\text { June, } \\
\text { ro16 }\end{array}$ & $\begin{array}{l}\text { May, } \\
\text { gri7 }\end{array}$ & $\begin{array}{c}\text { Nov., } \\
1917\end{array}$ & $\begin{array}{l}\text { Fcb., } \\
1920\end{array}$ & $\begin{array}{l}\text { July, } \\
\text { xg2o }\end{array}$ & \\
\hline \multirow{2}{*}{\multicolumn{2}{|c|}{$\begin{array}{l}\text { Flank becf ... } \\
\text { Flank mutton }\end{array}$}} & 132 & 99 & 99 & 91 & 79 & 99 & 74 & 46 & \\
\hline & & 132 & 88 & 88 & 88 & 103 & 107 & 95 & 一 & \\
\hline Bacon . & $\ldots$ & 256 & 203 & 187 & 179 & I 29 & 100 & 95 & 90 & 0 \\
\hline Checse & $\ldots$ & 241 & 171 & 196 & 152 & 89 & I I I & 83 & 89 & \\
\hline Ifilk & $\ldots$ & - & - & - & - & 90 & 68 & 49 & 39 & \\
\hline Margarine. & $\cdots$ & 659 & 587 & $5^{87}$ & 504 & 298 & 255 & 298 & 298 & 277 \\
\hline Bread .. & $\ldots$ & 810 & 607 & 607 & 572 & 405 & 527 & 495 & 384 & 05 \\
\hline Flour & $\ldots$ & I 155 & 770 & 798 & 722 & 471 & 722 & 722 & 722 & \\
\hline Oatmcal & $\cdots$ & 1512 & 753 & 850 & 814 & 331 & $4^{67}$ & 04 & - & \\
\hline Barley & $\ldots$ & 825 & 660 & $55^{\circ}$ & 471 & 330 & 412 & 314 & $3^{14}$ & 14 \\
\hline plit peas. & $\ldots$ & 827 & $55^{2}$ & 414 & 325 & 325 & 297 & 325 & 325 & \\
\hline Haricot bean & os & 640 & 640 & 533 & 457 & 116 & 271 & 406 & 457 & 82 \\
\hline I.entils .. & $\ldots$ & 648 & 463 & 216 & 463 & 217 & 217 & $27 \mathrm{I}$ & 325 & $27 \mathrm{I}$ \\
\hline ice... & $\cdots$ & 815 & 815 & 815 & 652 & 466 & 466 & 408 & 233 & $25^{1}$ \\
\hline grar & $\cdots$ & 930 & $3 \mathrm{I}$ & 496 & 372 & 347 & 317 & 228 & ז33 & 207 \\
\hline atoes & $\cdots$ & 542 & 542 & 723 & $27 t$ & 244 & 427 & 299 & 142 & \\
\hline
\end{tabular}

In view of the fact that, of the weekly wage of the workers earning 5os. a week or less, at any rate of those with families, $5^{\circ}$ to 60 per cent. of the income is legitimately spent in the purchase of food, it is suggested that the total

1 A family composed of father, mother, and children can be reduced to terms of "man" by the use of appropriate and well-established factors. Se Royal Society Food Requirements Report. 
cost of living should be the dominant factor in the determination of the level of the minimum wage. Such a mode of assessment would also form an equitable basis for the determination of the wage of the skilled worker, in so far that the increment to be added in payment of (r) skill, (2) compensation for work carried out under unpleasant or unhygienic conditions, or (3) extraheavy work, would be simply an addition to the minimum wage.

It is unquestionably true that there ought to be a statutory minimum wage. It is the unskilled worker who suffers most. No matter what the trade or occupation, it can be confidently asserted that, as a general rule, it will be found that the unskilled labourer is expending most energy and receiving least pay.

The assumption has been made that the purchase of food and the production of external muscular work are terms which are strictly interchangeable, and within the limits of the minimumwage-earning class this is true. Objection to the proposal to use food consumption as the basis of wage fixation might legitimately be raised on the ground that, with the great majority of wageearners, the purchase of food is not confined to the purchase for their own needs, but also for those of a family or other dependents. There is the further difficulty as to whether the minimum wage for men and women should be identical. There is absolutely no question about the fact that the average woman worker does not expend the same amount of energy as the average man, but this may be offset by another factor of wide application, that the majority of working women carry on at the same time housework in their own homes, where the expenditure in energy may easily compete in severity with the work done outside.

Science may seem at times to be cold and unsympathetic, even harsh, but, nevertheless, it is only when the facts are observed in a clear and unimpassioned manner that the truth can be found. Far from viewing man as a mere machine for the conversion of the latent energy of food into the potential energy of work, science is fully alive to the fact that this is only one aspect of vital activity, that there is a psychic side of life -everything that makes up the environmentwhich plays an equally important part in the lifehistory.

The purely energy side of the subject cannot be the sole criterion for the determining of wages. Food alone will not suffice to keep men going; it must be consumed under conditions which are satisfactory-conditions, it is true, which vary, at present, with the social status of the individual. There must be a sufficiency of money for a reasonable expenditure on various small luxuries, for entertainment, and for the various amenities of life, the absence of which makes life for the majority of people scarcely worth living. There is no question, then, as many Labour leaders seem to imagine, that an attempt is being made to reduce the manual worker to the level of serfdom. ${ }^{2}$

E. P. C.

2 The Editor has very kiudly directed the writer's attention to a footnote in Mr. H. G. Wells's "Outline of History" (p. 519 ; Cassell and Co., 1920) with reference to an experiment of the Oneida Silver Co. In the assessment of the weekly wage reference is made to the cost of staple commodities an common necossities, and the worker receives his wages plus a percentag representing the advance of the cost of food, etc., from a standard value.

\section{Obituary.}

\section{Dr. Max Margules.}

THE news of the death of Dr. Max Margules on October 4, which reached this country a fortnight ago, is rendered particularly sad by the announcement in Tuesday's Times that "his death was due to starvation. $\mathrm{He}$ had been living on a pension of 400 crowns a month (which is equivalent to $8 s$. ), and he was too proud to beg for assistance." Dr. Margules was born in $185^{6}$ at Brody, in Galicia. After studying at Vienna and Berlin, he entered the Austrian Meteorological Service in 1880 , and became secretary of the Institute at Vienna in 1890.

In 1882 Lord Kelvin suggested that the explanation of the regular semi-diurnal variation of the barometer, which has a range of more than two millibars in equatorial regions, might be found in the coincidence of a free period of oscillation of the atmosphere with the period of the solar gravitational tide. Lord Rayleigh in 1890 showed that if the rotation of the earth were neglected, a rough computation of the free periods led to values of 23.8 and 13.7 hours, so that Kelvin's hypothesis became at any rate a possiNo. $266 \mathrm{I}$, VOL. IO6] bility, although the actual values obtained by Rayleigh would have indicated a bigger diurnal and a smaller semi-diurnal baromete $\hat{r}^{\text {variation. }}$ Margules, in the same year, attacked the problem of computing the pressure oscillations of the atmosphere on a rotating globe, and found that for an atmosphere with a temperature of $268^{\circ}$ absolute $\left(-5^{\circ}\right.$ C. $)$ the free period was exactly twelve hours.

In 1892 and 1893 Margules contributed to the Sitzungsberichte of the Vienna Academy a series of masterly papers on the motion of the air on a rotating spheroid. These papers are little known to English meteorologists, as they were not included in the collection of papers and trans. lations issued by the Smithsonian Institution in the volumes of "Mechanics of the Earth's Atmosphere."

Margules contributed to the Year Book of the Meteorological Institute of Vienna for Igo3 a comprehensive discussion of the energy of storms. He showed that the atmospheric phenomena associated with storms would arise if two masses of air of different temperatures were in 